CORD Vol. XVIII No. 1, 2002

\title{
ELECTRON MICROSCOPIC EVIDENCE FOR PURIFICATION OF COCONUT ROOT (WILT) DISEASE PHYTOPLASMA
}

\author{
By \\ M. Mayilvaganan and J. J. Solomon ${ }^{I}$
}

\begin{abstract}
Root (wilt) disease phytoplasma was purified from diseased coconut tissues using discontinuous Percoll gradient centrifugation method. Crude sap prepared from coconut was layered on a discontinuous Percoll gradient of 15, 30, 50 and 60\%(v/v). After centrifugation at 20,000 $\mathrm{g}$ for $30 \mathrm{~min}$, the turbid fraction formed on the top of $30 \%$ gradient in the diseased plant material was recovered, processed and fixed for electron microscopy. Electron microscopic examination of sections prepared from purified preparation of diseased plant material showed typical cells of root (wilt) phytoplasma with heterogeneous sizes and more or less spherical shape that are similar to those found in sieve elements of diseased tissues and salivary glands of infective (viruliforms) insect vectors. These purified phytoplasma bodies showed trilaminar membrane with internal materials of ribosome granules and DNA fibrils. However, the yield in terms of number of cells was fewer and in addition to intact bodies, free membranes and empty bodies lacking internal contents also were observed.
\end{abstract}

1 Central Plantation Crops Research Institute, Regional Station, Kayangulam, Krishnapuram - 690 533, Kerala, India. 


\section{INTRODUCTION}

Root (wilt) disease of coconut (Cocos nucifera L.) is prevalent in all the districts of Kerala State, India and in some of the districts of Tamil Nadu State bordering Kerala in different intensity. This major non-lethal disease of coconut palm caused by phytoplasma, is detected in phloem sieve tubes of diseased palms by electron microscopy (Solomon, et al., 1983a). Constant association of this phloem bound mollcutes in tissues of diseased palms and its conspicuous absence in healthy palms led to intensive research in areas of transmission of phytoplasma of the tissues using putative insect vectors (Mathen et al., 1987) and parasitic dodder laurel (Sasikala et al., 1988) and differential chemotherapeutic trials using various antibiotics (Pillai et al., 1991). Though, these lines of evidences implicate phytoplasma as casual agent of the root (wilt) disease, the culturing of the pathogen (despite extensive efforts) and Kock's postulates requirements have not been fulfilled. Since the phytoplasma is recalcitrant to in vitro culturing, purification of this organism is needed for preparation of phytoplasma-specific antiserum and biochemical and molecular characterization.

Polyclonal antiserum has been produced against partially purified antigenic protein present in root (wilt) phytoplasma infected tissues of palms (Solomon et al., 1983b). This antiserum shows considerable cross-activity due to antibodies to host proteins. Development of a sensitive and highly specific detection method for pathogen will facilitate field studies. At present, two procedures are being extensively employed; immunological detection -serological assay using enzyme-linked immunosorbent assay (Jiang et al., 1988) and dot blot assay (Gomez et al., 1996) and molecular detection - PCR amplification of the conserved 16S 
RNA gene of phytoplasma using universal primers (Harrison et al., 1994; Thomas and Balasundaran, 1999).

In a previous paper (Mayilvaganan, et al., 2001), some biochemical evidences were shown for purification of coconut root (wilt) phytoplasma. In this paper, electron microscopic evidence for purification of phytoplasma is described.

\section{MATERIALS AND METHODS}

Non-chlorophyllous spear leaf tissues from root (wilt) diseased coconut palms in the early stage of disease were collected from C.P.C.R.I. Regional Station, Kayangulam, and used for the study. A modification of the phytoplasma-purification protocol described by Jiang and Chen (1987) and adopted by Mayilvaganan, et al., (2001) was used in this study. A $100 \mathrm{~g}$ of pre-chilled leaf tissues was ground in $300 \mathrm{ml}$ of chilled isolation medium, containing 0.3 M D-mannitol, $4 \mathrm{mM}$ L-cysteine, $1 \mathrm{mM}(\mathrm{N}-$ morpholino)-propane sulfonic acid (MOPS) buffer, $1 \mathrm{mM}$ ethylenediamine tetraacetic acid (EDTA) and $1 \%$ polyvinyl pyrrolidone (PVP), $\mathrm{pH} 7.2$ for $2 \mathrm{~min}$. The sap from ground tissue was filtered and squeezed through three layers of muslin cloth. The remaining fibrous material was ground in $200 \mathrm{ml}$ of isolation medium for $30 \mathrm{~s}$. The sap was squeezed through muslin cloth and the pooled sap was centrifuged at $3000 \mathrm{~g}$ for $8 \mathrm{~min}$ (low speed). The supernatant was centrifuged at $35000 \mathrm{~g}$ for $30 \mathrm{~min}$ (high speed) in Beckman-L5-50 B Ultracentrifuge. The pellets were dissolved in $50 \mathrm{ml}$ chilled suspending medium $(0.3 \mathrm{M}$ D-mannitol and $20 \mathrm{mM}$ MOPS buffer, $\mathrm{pH}$ 7.0). The suspension was centrifuged again at low and high speed. The final pellets were suspended in about $5 \mathrm{ml}$ of suspending medium and clarified at $3000 \mathrm{~g}$ for $8 \mathrm{~min}$. Similarly, leaf samples of healthy palms (collected from disease-free areas in Tamil Nadu State) were also processed identically for comparison. 
About $0.8 \mathrm{ml}$ of preparation was added to the top of discontinuous gradients of $15 \%(9 \mathrm{ml}), 30 \%(9 \mathrm{ml}), 50 \%(5 \mathrm{ml})$ and $60 \%(5 \mathrm{ml})$, prepared using density medium (nine parts of Percoll, from Pharmacia Biotech, Sweden, and one part v/v of $2.5 \mathrm{M}$ sucrose) and diluting medium (0.25 M sucrose and $10 \mathrm{mM}$ MOPS buffer, $\mathrm{pH}$ 7.0) in 25-x 79-mm Ultra-Clear $38.5 \mathrm{ml}$ centrifuge tubes (Beckman Instrument Inc., Palo Alto, CA). After centrifugation of the tubes at $20000 \mathrm{~g}$ for $30 \mathrm{~min}$, a turbid zone observed on top of $30 \%$ gradient in the diseased preparation and the corresponding zone from healthy preparation tubes were recovered. The fraction was diluted with suspending medium, centrifuged at $100000 \mathrm{~g}$ for $120 \mathrm{~min}$ to remove Percoll. The pellets that accumulated on the surface of Percoll was carefully harvested, suspended in phosphate buffered saline (PBS, $\mathrm{pH}$ 7.0) and prepared for electron microscopy.

The recovered fraction was mixed with $1 \%$ molten agar and spread on micro slides. After gelling, agar was sliced into pieces of $2 \times 5 \mathrm{~mm}$ and fixed using $2 \%$ glutaraldehyde in $0.1 \mathrm{M}$ phosphate buffer, $\mathrm{pH} 7.2$, post fixed in $2 \%$ osmium tetroxide, dehydrated and embedded in Spurr. Ultra-thin sections of $600-700 \mathrm{~A}^{0}$ were made in LKB IV Ultratome and the sections were picked on 200 mesh uncoated copper grid, stained with uranyl acetate and lead citrate and observed under Carl Zeis EM 109 Turbo operating at an acceleration voltage of $50 \mathrm{KV}$.

\section{RESULTS AND DISCUSSION}

Electron microscopic examination of sections of fractions from diseased palm showed typical cells of phytoplasma with heterogeneous sizes mostly spherical or oval shape. The sections showed cells of clear ultrastructures with internal content of ribosomal granules and DNA fibrils. However the yield in terms of 
number of cells were fewer (Figure). Sections of fraction recovered from healthy control palms preparations did not contain phytoplasmas. The structure of phytoplasmas was identical to those found in sieve tubes of phloem tissues of the diseased palms and salivary glands of infected insect vectors. Plant organelles and filamentous cells were not observed in the sections of the purified preparations indicating this preparation was free of contaminants of host material. The recovered cells were physically intact with little damage to cellular integrity though few cells were seen in ruptured degenerate form lacking internal content and as free membranes.

As phytoplasmas have defied all attempts to culture in vitro, development of a serological - detection procedure requires the extraction of phytoplasma in highly purified form free from host contaminants to be used as immunogen. Among the methods in vogue, use of Percoll-gradients of Jiang and Chen (1987) was found suitable to purify coconut root (wilt) phytoplasma as purification by immunoaffinity involves antibodies specific to the pathogen (Jiang et al., 1988 and Seddas et al., 1995). Percoll, a medium used for density gradient centrifugation, is non-toxic colloidal silica coated with PVP, is compatible with living cells, and used for purification of aster yellows phytoplasma (Jiang and Chen, 1987) and china- tree decline phytoplasma (Gomez et al., 1996).

In this study, only diseased material produced the turbid zone of 5-8 $\mathrm{mm}$ at the top of $30 \%$ step gradient revealing presence of phytoplasma cells in diseased palm extract (Mayilvaganan et al., 2001). During purification in this study, when the low speed centrifugation was limited to $1500 \mathrm{~g}$, host plant organelles were also seen along with phytoplasmas indicating such a low speed is not sufficient to remove plant materials from phytoplasma. Hence, the low speed centrifugation was increased to $3000 \mathrm{~g}$ to remove host plant materials and to obtain phytoplasma free from cell 
organelles. Fewer numbers of phytoplasma in purified preparation suggests low phytoplasma titer in infected tissues, a fact corroborated in ultra-structural studies of tissues (Solomon, 1997). Thomas (1979) after electron microscopic examination of 21 species of lethal yellowing palms observed that phytoplasma concentration in coconut is the lowest. Distribution of the pathogen within the vascular bundle is sparse and not all the sieve tubes in phloem patch contained them.

Phytoplasmas found in sieve tubes of infected palms and insect vectors are pleomorphic. The purified phytoplasmas by this method normally oblong to spherical shape owing to high centrifugal force applied during purification procedure and high fluidity of the phytoplasmas(Jiang and Chen, 1987).

\section{CONCLUSIONS}

Purified phytoplasmas maintained their cellular integrity indicating suitability of the method adopted for isolation and purification. The purification of root (wilt) phytoplasma will eventually enable to produce pathogen-specific antiserum, which can be applied for large scale screening of plant and putative vectors. In addition, the purified preparation will permit to study biological, biochemical and molecular properties of this recalcitrant pathogen. 


\section{ACKNOWLEDGEMENT}

The authors gratefully acknowledge the Director, CPCRI, Kasaragod and Head, CPCRI-RS, Kayangulam for providing facility for this piece of work.

\section{REFERENCES}

GOMEZ, G. G., CONCI, L. R., DUCASSE, D. A. and NOME, S. F. 1996. Purification of phytoplasma associated with China-tree (Melia azedarach L) decline and the production of a polyclonal antiserum for its detection. $J$. Phytopathol. 144: 473-477.

HARRISON, N. A., RICHARDSON, P. A., KRAMER, J. B. and Tsai, J. H. 1994. Detection of mycoplasma-like organism associated with lethal yellowing disease of palms in Florida by polymerase chain reaction. $P l$. Pathol. 43: 998-1008.

JIANG, Y. P. and CHEN, T. A. 1987. Purification of mycoplasmalike organisms from lettuce with aster yellows disease. Phytopathol. 77: 949-953.

JIANG, Y. P., LEI, J. P. and CHEN, T. A. 1988. Purification of aster yellow agent from diseased lettuce using affinity chromatography. Phytopathol. 78: 828-831.

MATHEN, K., SOLOMON, S. S., RAJAN, P. and GEETHA, L. 1987. Electron microscopic evidence on the role of Stephanitis typica (Distant) as vector of coconut root (wilt) disease. Curr. Sci. 56: 1339-1341. 
MAYILVAGANAN, M., GUPTA, A. and CHITHRA, K. R. 2001. Biochemical evidences for purification of phytoplasma of root (wilt) disease of coconut. J. Pl. Biol. 28: 1-6.

PILLAI, N. G., CHOWDAPPA, P., SOLOMON J. J. and MATHEW, J. 1991. Remission of symptoms of root (wilt) of coconut injected with oxytetracycline-HCl. $J$. Plantn. Crops. 19: 191-194.

SASIKALA, M., MATHEN, K., GOVINDANKUTTY, M. P., SOLOMON, J. J. and GEETHA, L. I988. Transmission of mycoplasma-like organisms from Cocos nucifera with root (wilt) to Catharanthus roseus by Cassytha filiformis. Neth. J. Pl. Pathol. 94: 191-194.

SEDDAS, A., MEIGNOZ, R., KUSZALA, C. and BOUDENPADIEU, E. 1995. Evidence for physical integrity of flavescence doree phytoplasmas purified by immunoaffinity from infected plants or leafhoppers and the plant pathogenicity of phytoplasmas from leafhoppers. Pl. Pathol. 44: 971-978.

SOLOMON, J. J. 1997. Current status of research on root (wilt) disease of coconut in India. In: Proceedings of an International Workshop on Lethal Yellowing- Line Diseases of Coconut (eds. Eden-Green, S. J. and Ofori, F.), Natural Resources Institute, Chatham, U. K., pp. 85-96.

SOLOMON, J. J., GOVINDANKUTTY, M. P. and NIENHAUS, F. 1983. Association of mycoplasma-like organisms with coconut root (wilt) disease in India. Z. Pflkrankh Pflschutz. 90: 295-297. 
SOLOMON, J. J., SASIKALA, M. and SHANTA, P., 1983. A serological test for the detection root (wilt) disease of coconut; in: Coconut Research and Development (ed. Nayar, N. M.) Wiley Eastern Ltd., pp 401-405.

THOMAS, D. L. 1979. Mycoplasmalike bodies associated with lethal yellowing of palms in Florida. Phytopathol., 69: 928978.

THOMAS, S. and BALASUNDARAN, M. 1999. Detection of sandal spike phytoplasma by polymerase chain reaction. Curr. Sci. 76: 1574-1576. 
CORD Vol. XVIII No. 1, 2002

\section{Legend for Figure:}

Fig. Electron micrograph of phytoplasmas purified from root (wilt) diseased coconut. Heterogeneous cells with ribosomal granules, DNA fibrils and unit trilaminar membrane.

Bar $=0.2 \mu \mathrm{M}$.

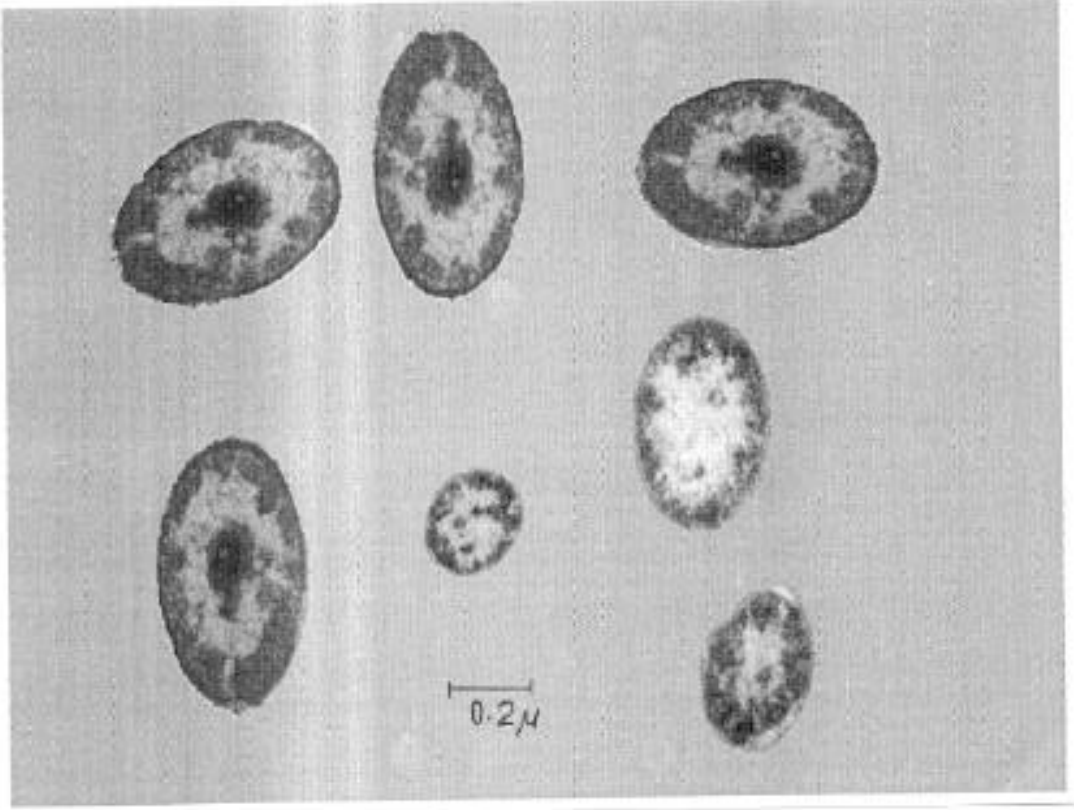

